\title{
Forces Generated in the Parking Brake of the Pallet Locking System
}

\author{
Leopold Hrabovský ${ }^{*}$, Tomáš Mlčák², Gustav Kotajný3 \\ 1 VSB Technical University of Ostrava, Faculty of Mechanical Engineering, Institut of Transport, 17. listopadu \\ 2172/15, 70800 Ostrava - Poruba, Czech Republic \\ 2 VSB Technical University of Ostrava, Faculty of Electrical Engineering and Computer Science, Department of \\ Electrical Engineering, 17. listopadu 2172/15, 70800 Ostrava - Poruba, Czech Republic \\ 3 KOMA-Industry s.r.o., Ruská 514/41, 70602 Ostrava - Vítkovice, Czech Republic \\ * Corresponding author's e-mail: leopold.hrabovsky@vsb.cz
}

\begin{abstract}
Automatic parking systems are parking structures with a computer-controlled automated vehicle loading and unloading process using sophisticated technological equipment. The paper describes a construction design for a pallet locking system, which is used to lock parking pallets with or without a vehicle, at a particular location and floor, that is, in a rack cell. This is one of the basic design concept variants of "Multi-Tower" automatic parking systems. This concept makes it possible to store cars stacked in rack cells. Cars on pallets are guided to the vertical cells of the parking system, stacked above each other on pallets, by an electric freight traction elevator. Pallets are stacked into the horizontal cells, on either or both sides, on a given floor of the parking system by means of a chain transfer device. After the pallet has been guided to a particular position, the pallet must be fixed in this position by the pallet locking system so that when the vehicle needs to be retrieved, the chain transfer device can again latch onto it and move it to the traction lift cage without any problems. The locking system also functions as a brake for the pallet carrying the parked vehicle. The paper also presents the theoretical calculations of the pallet brake, which is a crucial element of the pallet locking system of the conceptual variant of the "MULTI TOWER" automatic parking system.
\end{abstract}

Keywords: automated parking system, locking system, pallet brake.

\section{INTRODUCTION}

Cities and development projects that include green space and common areas in which people can interact are more beautiful, livable, safe and desirable to businesses, tourists and residents. However, attracting people to these urban areas means attracting and parking their cars.

Numerous research studies (by MIT, Transportation Alternatives and others) state that $30 \%$ to $50 \%$ of traffic congestion in city centers is generated by drivers searching for a parking space. A lack of sufficient downtown parking is often due to the large space required for conventional ramp parking [8].

Automatic parking systems [5,6] are relatively complex technologies with a computer-controlled automated vehicle loading and unloading process using a highly-advanced technology.

Company see [6] possesses the capacity and technical knowledge to handle the entire process, including the technical specifications for installation, in the most cost-efficient and effective way possible. All of this has allowed for the construction of highly prestigious public and private parking facilities in many parts of the world. PARKPIU's extensive experience in the industry has allowed for the development of products and systems able to solve the most varied of problems encountered in the realization of mechanized parking facilities.

Maximizing space is critical for architects and developers particularly on a small site. If too much space is consumed by parking requirements, 
too little saleable space may be left for the project to be viable. Also, green space and open areas for design or LEED certification may be compromised in order to fit more parking.

Robotic Parking Systems' RPS 100 [7] automated parking garage is the ideal solution for small sites with a high demand for parking. This automatic parking structure uses only $50 \%$ of the land area typically required by a conventional ramp-style parking garage. The RPS 100's highspeed efficiency and fast retrieval times ensure rapid throughout (the number of cars in and out per hour) and a satisfying user experience.

Architects and developers regularly have to compromise design or reduce saleable space to accommodate required parking. Sometimes, the large amount of land area required for parking makes the entire project nonviable. The design concept variants [1] of automatic parking systems offer a safe and intelligent way of collective short-term and long-term (subscriber) car parking on the principle of a handling and storage model.

They are designed especially for parking of passenger cars but can also be used for parking of vans or trucks. They address situations with a lack of parking spaces and a lack of free space for the implementation of standard surface parking, especially in housing estates, in the centers of large cities, in administrative units, hotels, airports, railway stations and $\mathrm{P} \& \mathrm{R}$ type parking lots.

The design variant of the "MULTI TOWER" automatic parking system [1] stores cars on pallets in cells stacked above each other, as shown in Figure 1. After inserting a pallet in a specific rack cell on one side or the other of a given floor of the automated parking system, the pallet must be secured in a strictly determined position. The pallet fixing is ensured by a locking system consisting of two basic construction components, the "pallet brake" and the "brake catch".

\section{Construction Design of Pallet Locking System}

Insertion of the pallet with the vehicle into the designated cell on the designated floor of the rack is provided by a chain conveyor installed on the freight elevator cage [3]. The chain speed $\mathrm{v}_{\mathrm{r}}[\mathrm{m} / \mathrm{s}]$ of the chain conveyor is controlled by the speed of the electric motor, which is regulated by the frequency converter. Two "brake track" pieces are mounted on the bottom of the pallet in the given direction, see Figure 2 and Figure 3.

The bodies of the pallet brakes $\underline{1}$, see Fig. 4 , of the pallet locking system, are fastened to the lower steel beams of the rack cells by bolted connections, see Figure 3.

Bearings 14, see Figure 4, are connected the pulley holder $\underline{2}$ by a pin $\underline{5}$. The distance of the bearings 14 from the recessed surface in the brake body 1 is delimited by the length of the compression coil spring 16 .

At a certain point when the pallet is inserted into the rack cell, moving at a speed $\mathrm{v}_{\mathrm{p}}=\mathrm{v}_{\mathrm{r}}[\mathrm{m}$. $\mathrm{s}^{-1}$, and reaches a certain position, the bearings of the brake 14 begin to roll along the beveled part of the brake track, see Figure 2. In time $t_{z 1}[s]$, see relationship (1), when the bearings 14 roll on the beveled part of the brake track, the coiled cylindrical spring 16 is gradually compressed. The compressible cylindrical spring, 16 V16-102; see [2], with a rectangular wire $\mathrm{b} \times \mathrm{h}=3.2 \times 1.5 \mathrm{~mm}$, free length $\mathrm{L}_{0}=102 \mathrm{~mm}$, external diameter $\mathrm{DH}=16 \mathrm{~mm}$ and internal diameter $\mathrm{D}_{\mathrm{d}}=8 \mathrm{~mm}$; increases in stiffness $\mathrm{k}_{\mathrm{p}}=7.8 \mathrm{~N} / \mathrm{mm}$.

In time $\mathrm{t}_{\mathrm{z} 1}$ [s], i.e., in the time, in which the brake bearings 14 roll away along the beveled part of the brake track, the pallet moves in a horizontal direction by a length of $\mathrm{L}_{\mathrm{z} 1}=136.63 \mathrm{~mm}$, see Figure 2.

$$
\mathrm{t}_{\mathrm{z} 1}=\mathrm{L}_{\mathrm{zl}} / \mathrm{v}_{\mathrm{p}}[\mathrm{s}]
$$
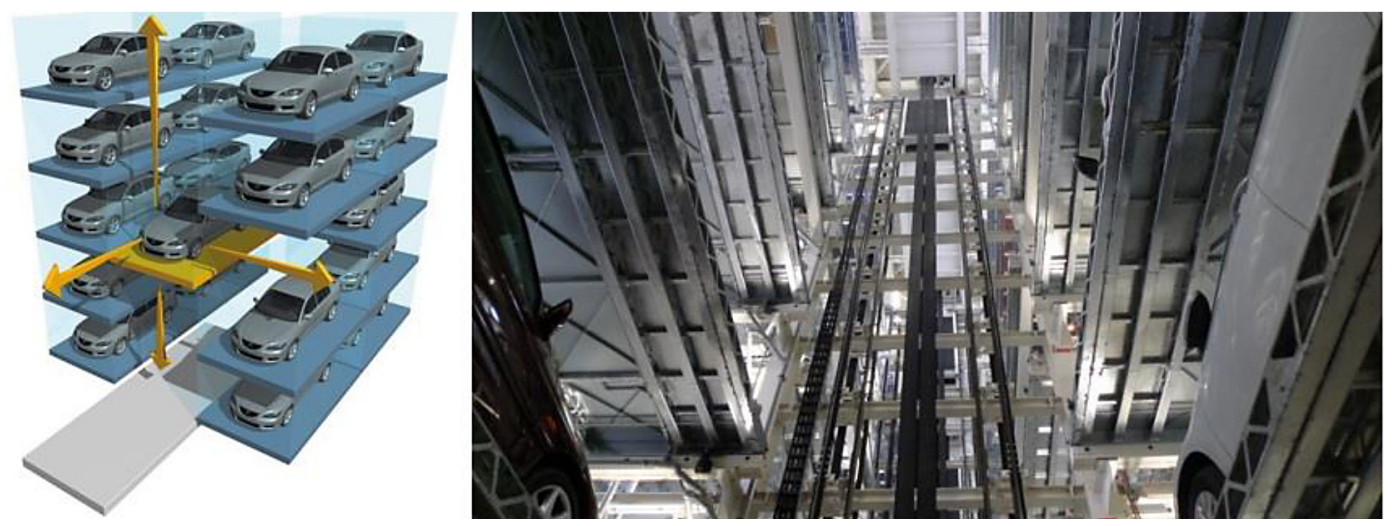

Fig. 1. Design variant of the "MULTI TOWER" automatic parking system 


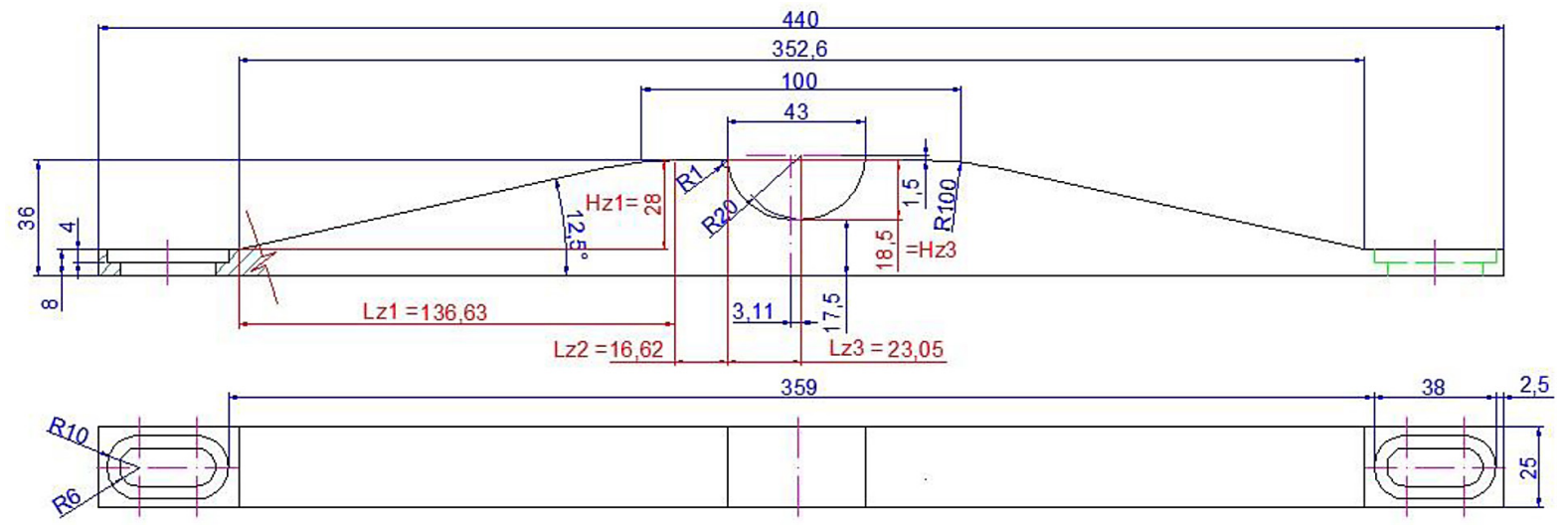

Fig. 2. Brake track of the pallet locking system of the "MULTI TOWER" design for an automatic parking system
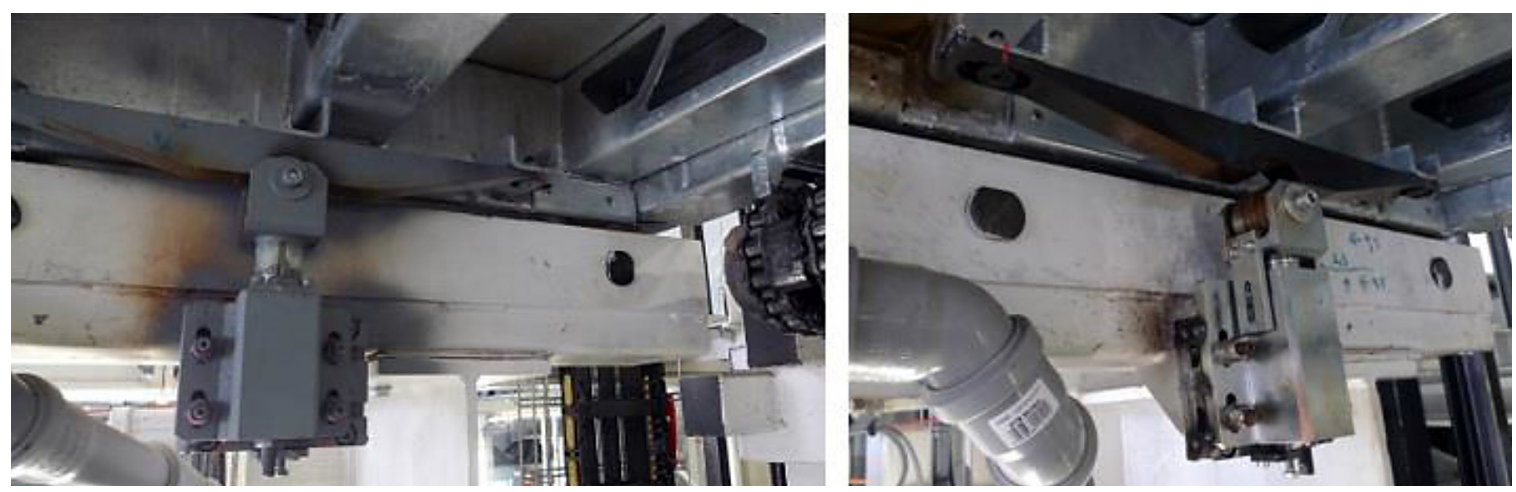

Fig. 3. Pallet locking system of the "MULTI TOWER" automatic parking system

After the elapsing of time $t_{z 1}[s]$ the spring 16 compresses by a value of $\mathrm{H}_{\mathrm{z} 1}^{\mathrm{z1}}=28 \mathrm{~mm}$, see Figure 2. At a compression of the spring of $\mathrm{H}_{\mathrm{z} 1}$ $[\mathrm{mm}]$ the spring $\underline{16}$ exerts a pushing force $\mathrm{F}_{\mathrm{p} 1}[\mathrm{~N}]$ see relationship (2a).

$$
\mathrm{F}_{\mathrm{p} 1}=\mathrm{H}_{\mathrm{z} 1} \cdot \mathrm{k}_{\mathrm{p}}=28 \cdot 7,8=218,4 \mathrm{~N}
$$

On Figure 4, item $\underline{3}$ indicates the adjusting bolt. The adjusting bolt $\underline{3}$ makes it possible to change the initial spring pressure $\underline{16}$ by a maximum value of $\mathrm{H}_{\mathrm{z}}=13 \mathrm{~mm}$.

At the maximum initial compression of the spring $\mathrm{H}_{z}[\mathrm{~mm}]$ and after the elapse of the time $\mathrm{t}_{\mathrm{z} 1}$ [s], where the spring $\underline{16}$ was compressed by the value $\mathrm{H}_{\mathrm{z} 1}[\mathrm{~mm}]$ the spring $\underline{16}$ would generate a pushing force of $\mathrm{F}_{\mathrm{pl}}[\mathrm{N}]$ see relationship (2b).

$$
\begin{aligned}
\mathrm{F}_{\mathrm{p} 1} & =\left(\mathrm{H}_{\mathrm{z}}+\mathrm{H}_{\mathrm{z} 1}\right) \cdot \mathrm{k}_{\mathrm{p}}= \\
& =(13+28) \cdot 7,8=319,8 \mathrm{~N}
\end{aligned}
$$

In the subsequent text of the paper, the relationships will take into consideration the case where the initial spring compression $\mathrm{H}_{\mathrm{z}}[\mathrm{mm}]$ is equal to zero, that is, the adjusting bolt $\underline{3}$ does not exert any initial deformation of the spring $\underline{16}$.

In time $t_{72}$ [s], i.e., in the time, when the brake bearings $\underline{14}$ roll away along the beveled upper surface of the non-angled section of the brake track, the pallet moves in a horizontal direction by a distance of $\mathrm{L}_{\mathrm{z} 2}=16.62 \mathrm{~mm}$, see Figure 2 .

In time $t_{\mathrm{z3}}$ [s], i.e., in the time, during which the outer surfaces of the brake bearings 14 begin to make contact with the right inner surface of the recessed sector of the brake track, the pallet has shifted in a horizontal direction by a value of $\mathrm{H}_{\mathrm{z} 1}-\mathrm{H}_{\mathrm{z3}}=28-18.5=9.5 \mathrm{~mm}$, see Figure 2 . Upon compression of the spring $\mathrm{H}_{\mathrm{z} 1}-\mathrm{H}_{\mathrm{z} 3}[\mathrm{~mm}]$ the spring $\underline{16}$ exerts a pushing force of $\mathrm{F}_{\mathrm{p} 3}[\mathrm{~N}]$ see relationship (3).

$$
\begin{aligned}
\mathrm{F}_{\mathrm{p} 3} & =\left(\mathrm{H}_{\mathrm{z} 1}-\mathrm{H}_{\mathrm{z} 3}\right) \cdot \mathrm{k}_{\mathrm{p}}= \\
& =(28-18,5) \cdot 7,8=74,1 \mathrm{~N}
\end{aligned}
$$

When the exterior surfaces of the pallet brake bearings $\underline{14}$ contact the lower surface of the milled recess in the form of a circular segment 

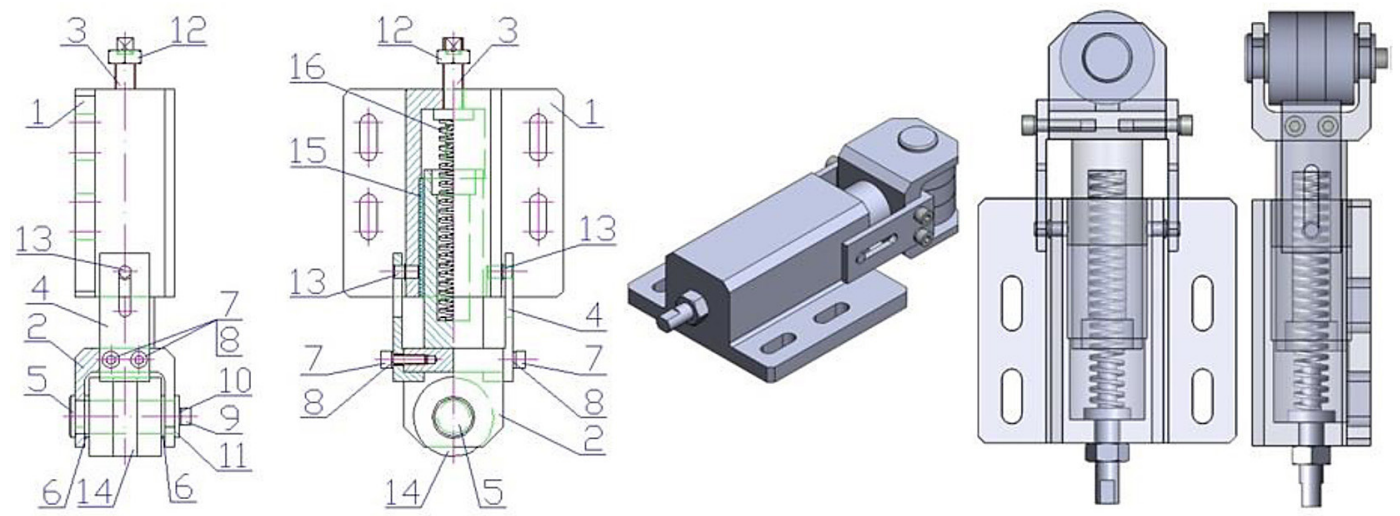

Fig. 4. Design variant No. 2 of the pallet brake of the pallet locking system

in the brake start, the pallet with the vehicle is in the "parking position". In the parking position, the horizontal pulling force exerted by the chains of the chain conveyor no longer acts on the pallet. The vehicle pallet is locked in the parking position by the pressure force $\mathrm{F}_{\mathrm{p} 3}[\mathrm{~N}]$ of the reshaped spring 14 , whose length $\mathrm{L}_{\mathrm{p}}[\mathrm{mm}]$ is indicated by the relationship (4).

$$
\begin{aligned}
\mathrm{L}_{\mathrm{p}} & =\mathrm{L}_{0}-\mathrm{H}_{\mathrm{z} 1}+\mathrm{H}_{\mathrm{z} 3}= \\
& =102-28+18,5=92,5 \mathrm{~mm}
\end{aligned}
$$

\section{SHUTDOWN OF ACTIVITY OF LOCKING SYSTEM}

In order to move a pallet in the parking position in the horizontal direction by a length of $1=$ $2 \mathrm{~mm}$, it is necessary to apply a force $\mathrm{F}[\mathrm{N}]$ to the pallet in the horizontal direction, see Figure 6.

The vertical displacement of the bearing axis $\underline{14}$ (held in the pulley holder $\underline{2}$ of the locking system) by the length $1=2 \mathrm{~mm}$, exerted by the acting force $\mathrm{F}_{\mathrm{x}}[\mathrm{N}]$ in the bearing axis $\underline{14}$, results in a vertical displacement of the bearing axis 14 by $\mathrm{y}_{\mathrm{TL}}=7.33 \mathrm{~mm}$, which causes a deformation of the cylindrical compression spring 14 .

At this time (the vertical shifting of the bearing axis 14 by a value of $1=2 \mathrm{~mm}$ ), it is possible, using Figure 5.b and Figure 6, to set the compression $\mathrm{s}_{\mathrm{p} 2}[\mathrm{~mm}]$ of the coiled spring $\underline{16}$ according to relationship (5).

$$
\begin{aligned}
\mathrm{s}_{\mathrm{p} 2} & =\mathrm{H}_{\mathrm{z} 1}-\mathrm{H}_{\mathrm{z} 3}+\mathrm{y}_{\mathrm{TL}}= \\
& =28-18,5+7,33=16,83 \mathrm{~mm}
\end{aligned}
$$

Compression $\mathrm{s}_{\mathrm{p} 2}[\mathrm{~mm}]$ of the coiled spring $\underline{16}$ causes the magnitude of the pushing force $\mathrm{F}_{\mathrm{p} 2}[\mathrm{~N}]$ in the spring $\underline{16}$, see relationship (6).

$$
\mathrm{F}_{\mathrm{p} 2}=\mathrm{s}_{\mathrm{p} 2} \cdot \mathrm{k}_{\mathrm{p}}=16,83 \cdot 7,8=131,27 \mathrm{~N}
$$

The required magnitude of the force $\mathrm{F}_{\mathrm{x}(\mathrm{l})}[\mathrm{N}]$ on the axis of the bearings 14 of the locking system, which causes a vertical movement of the axis of the bearings 14 by a magnitude of $\mathrm{y}_{\mathrm{TL}(1)}$ [mm], can be expressed according to Figure 6 and the equation (8).
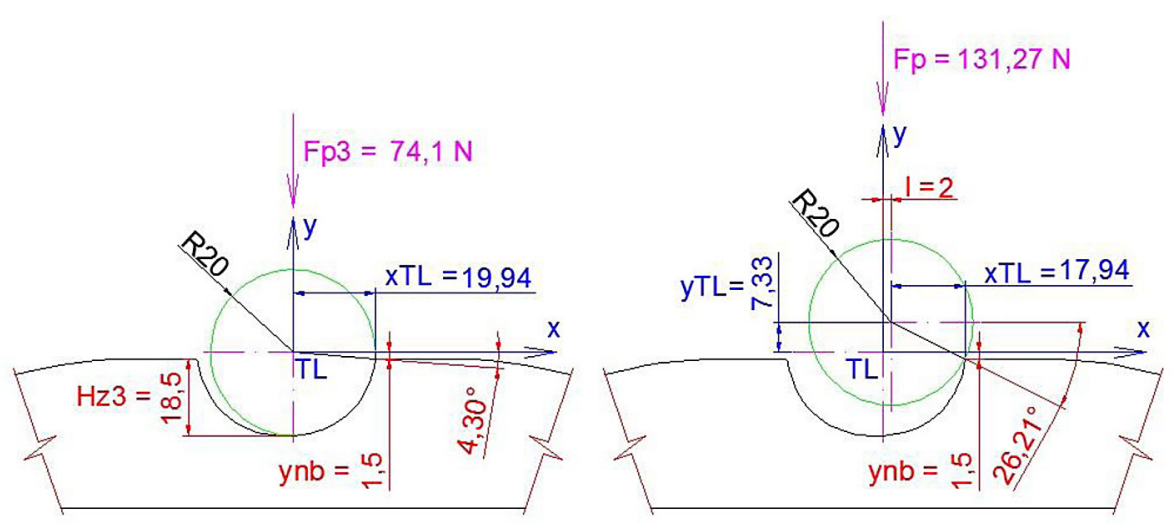

Fig. 5. Moving of the brake pulley in the horizontal direction from the recess in the shape of a circular cut-out of the brake track 


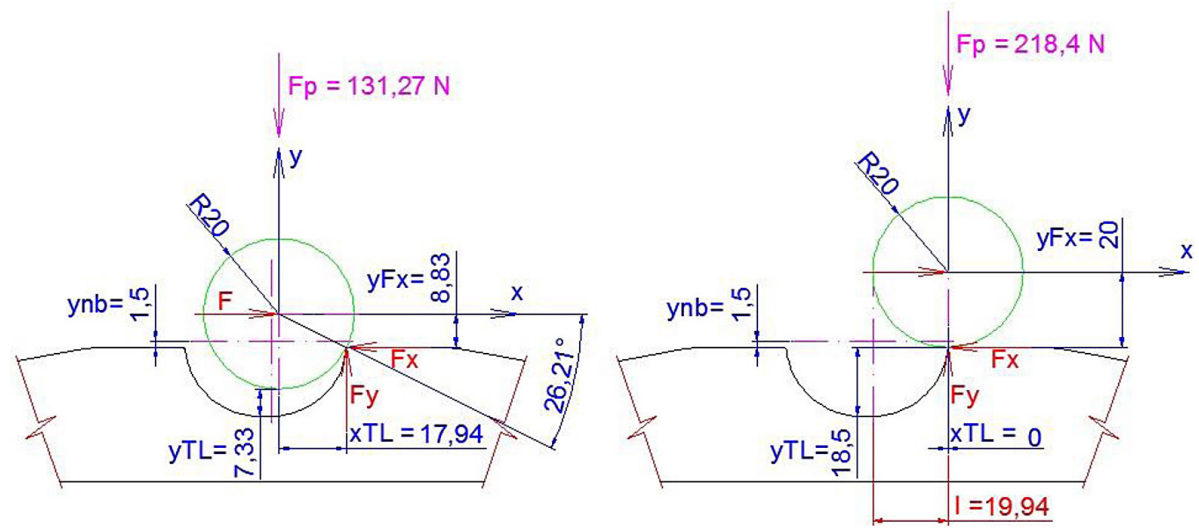

Fig. 6. The bearing pulley moved in the horizontal direction from the recess in the shape of a circular cut-out of the brake track

The sum equation of acting forces in the " $y$ " axis direction, according to Figure 6, is shown by the relationship (7).

$$
\begin{gathered}
\sum \mathrm{F}_{\mathrm{y}}=0: \mathrm{F}_{\mathrm{p}(\mathrm{l})}-\mathrm{F}_{\mathrm{y}(1)}=0 \Rightarrow \\
\Rightarrow \mathrm{F}_{\mathrm{p}(1)}=\mathrm{F}_{\mathrm{y}(\mathrm{l})}[\mathrm{N}] \\
\sum \mathrm{M}_{\mathrm{sL}}=0: \mathrm{F}_{\mathrm{x}(\mathrm{l})} \cdot \mathrm{y}_{\mathrm{Fx}(1)}-\mathrm{F}_{\mathrm{y}(1)} \cdot \mathrm{x}_{\mathrm{TL}(\mathrm{l})}=0 \Rightarrow \\
\Rightarrow \mathrm{F}_{\mathrm{x}(1)} \cdot\left(\mathrm{y}_{\mathrm{TL}(1)}+\mathrm{y}_{\mathrm{nb}}\right)-\mathrm{F}_{\mathrm{y}(1)} \cdot \mathrm{x}_{\mathrm{TL}(1)}=0 \Rightarrow \\
\Rightarrow \mathrm{F}_{\mathrm{x}(\mathrm{l})}=\frac{\mathrm{F}_{\mathrm{y}(1)} \cdot \mathrm{x}_{\mathrm{TL}(1)}}{\mathrm{y}_{\mathrm{TL}(1)}+\mathrm{y}_{\mathrm{nb}}}[\mathrm{N}]
\end{gathered}
$$

Where

$$
\begin{gathered}
\phi_{(1)}=\arcsin \frac{\mathrm{y}_{\mathrm{nb}}+\mathrm{y}_{\mathrm{TL}(\mathrm{l})}}{\mathrm{R}}= \\
=\arcsin \frac{\mathrm{y}_{\mathrm{Fx}(\mathrm{l})}}{\mathrm{R}}[\mathrm{deg}] \\
\mathrm{x}_{\mathrm{TL}(\mathrm{l})}=\mathrm{R} \cdot \cos \phi_{(\mathrm{l})}[\mathrm{m}] .
\end{gathered}
$$

In Table 1 and on Figure 7, the vertical movement values $\mathrm{y}_{\mathrm{TL}(1)}[\mathrm{mm}]$ of the bearing axes are shown, along with the compression of the coiled spring 16 and the angle $\phi_{(1)}[\mathrm{deg}]$ depending on the horizontal $1[\mathrm{~mm}]$ shifting of the bearing axis 14 .

Vertical displacement of the pulley axis, coil spring compression, angle $\phi_{(1)}[\mathrm{deg}]$ depending on horizontal displacement of the pulley axis. The Figure 8 shows the acting horizontal force $\mathrm{F}_{\mathrm{x}(\mathrm{l})}$ $[\mathrm{N}]$ in the bearing axis $\underline{14}$ and the compressive force $F_{y(1)}[N]$ produced by the spring $\underline{16}$ of the locking system in dependence on the horizontal 1 $[\mathrm{mm}]$ displacement of the bearing axis $\underline{14}$.

\section{Device for testing the pallet locking brake system}

A device has been prepared for experimental verification of the theoretically determined forces $\mathrm{F}_{\mathrm{x}(\mathrm{l})}[\mathrm{N}]$ and $\mathrm{F}_{\mathrm{y}(\mathrm{l})}[\mathrm{N}]$, when guiding the pallet brake into the recess in the brake track of the pallet locking system. A 3D model of experimental device shown in Figure 9.

The device makes it possible to attach one or the other design to a special bracket (not described

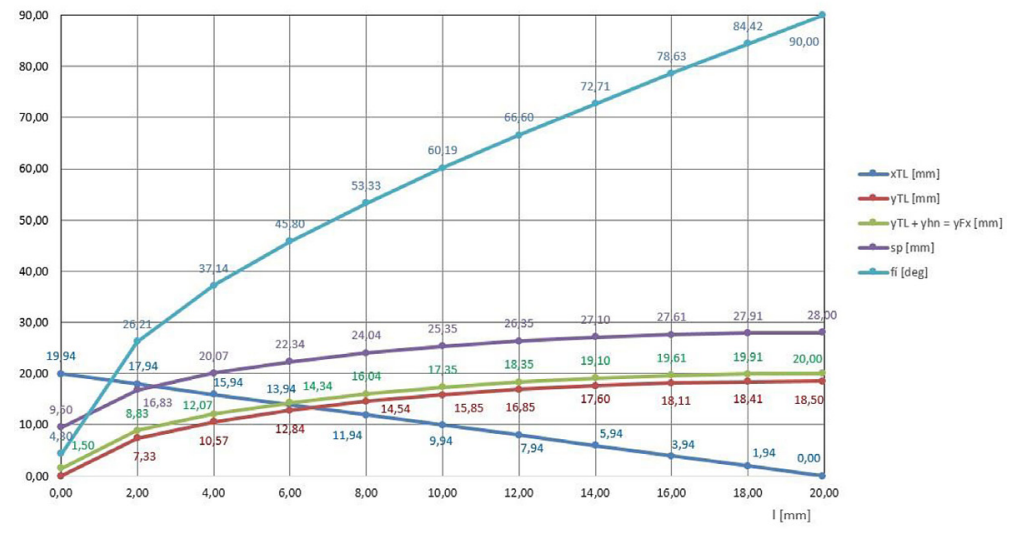

Fig. 7. Graph of the vertical movement values 
Table 1. Vertical movement values data

\begin{tabular}{|c|c|c|c|c|c|c|c|}
\hline $\begin{array}{c}\text { । } \\
{[\mathrm{mm}]}\end{array}$ & $\begin{array}{c}\mathrm{x}_{\mathrm{TL(1)}} \\
{[\mathrm{mm}]}\end{array}$ & $\begin{array}{c}\mathrm{y}_{\mathrm{TL}(1)} \\
{[\mathrm{mm}]}\end{array}$ & $\begin{array}{c}\mathrm{y}_{\mathrm{TL}(1)}+\mathrm{y}_{\mathrm{nb}}=\mathrm{y}_{\mathrm{Fx}(\mathrm{l})} \\
{[\mathrm{mm}]}\end{array}$ & $\begin{array}{c}\mathrm{s}_{\mathrm{p}(1)} \\
{[\mathrm{mm}]}\end{array}$ & $\begin{array}{c}\phi_{(I)} \\
{[\mathrm{deg}]}\end{array}$ & $\begin{array}{c}\mathrm{F}_{\mathrm{p}(1)}=\mathrm{F}_{\mathrm{y(l)}} \\
{[\mathrm{N}]}\end{array}$ & $\begin{array}{l}\mathrm{F}_{x(\mathrm{XI})} \\
{[\mathrm{N}]}\end{array}$ \\
\hline 0.00 & 19.94 & 0.00 & 1.50 & 9.50 & 4.30 & 74.10 & 985.04 \\
\hline 2.00 & 17.94 & 7.33 & 8.83 & 16.83 & 26.21 & 131.27 & 266.71 \\
\hline 4.00 & 15.94 & 10.57 & 12.07 & 20.07 & 37.14 & 156.55 & 206.74 \\
\hline 6.00 & 13.94 & 12.84 & 14.34 & 22.34 & 45.80 & 174.25 & 169.39 \\
\hline 8.00 & 11.94 & 14.54 & 16.04 & 24.04 & 53.33 & 187.51 & 139.58 \\
\hline 10.00 & 9.94 & 15.85 & 17.35 & 25.35 & 60.19 & 197.73 & 113.28 \\
\hline 12.00 & 7.94 & 16.85 & 18.35 & 26.35 & 66.60 & 205.53 & 88.93 \\
\hline 14.00 & 5.94 & 17.60 & 19.10 & 27.10 & 72.71 & 211.38 & 65.74 \\
\hline 16.00 & 3.94 & 18.11 & 19.61 & 27.61 & 78.63 & 215.36 & 43.27 \\
\hline 18.00 & 1.94 & 18.41 & 19.91 & 27.91 & 84.42 & 217.70 & 21.21 \\
\hline 19.94 & 0.00 & 18.50 & 20.00 & 28.00 & 90.16 & 218.40 & 0.00 \\
\hline
\end{tabular}

in more detail in this paper) of the pallet locking brake, which is then allowed to move vertically thanks to the rotation of the screw of the screw spindle [4], the nut of which is attached to the vertical beams of the frame structure. The pressure force $\mathrm{F}_{\mathrm{x}(\mathrm{l})}[\mathrm{N}]$ generated by the rotating screw of the screw spindle is detected by the tensometric force sensor and its progress over time (during the rolling of the bearings of the locking brake along the selected brake track) is recorded by the measuring apparatus.

Due to the design of the locking brake, the spring $\underline{16}$ in the brake housing 1 is compressed during the rolling of the bearings 14 mounted in the brake bearing bracket $\underline{2}$ along the angled and the straight part of the brake ramp. The brake body bracket is also connected to the upper frame beams by a tensometric strain gauge. The vertical force $\mathrm{F}_{\mathrm{y}(\mathrm{l})}[\mathrm{N}]$, which is directly proportional to the magnitude of the compressive force exerted by the deformation of the coil spring 16, is detected and recorded by the force sensor horizontally moving over the upper surface of the brake ramp.

\section{SolidWorks}

Both pallet brake system designs (one is shown in Figure 3) of the "MULTI TOWER" automatic pallet parking system, as well as component parts of the construction design of the experimental equipment, will be described in detail in the subsequent paper.

The experimental values and measured waveforms $\mathrm{F}_{\mathrm{x}(\mathrm{l})}[\mathrm{N}]$ a $\mathrm{F}_{\mathrm{y}(\mathrm{l})}[\mathrm{N}]$ will also be evaluated in the upcoming paper and these will be verified with theoretical values of horizontal $\mathrm{F}_{\mathrm{x}(\mathrm{l})}[\mathrm{N}]$ and the vertical forces $\mathrm{F}_{\mathrm{y}(\mathrm{l})}[\mathrm{N}]$ shown in Table 1 and Figure 8.

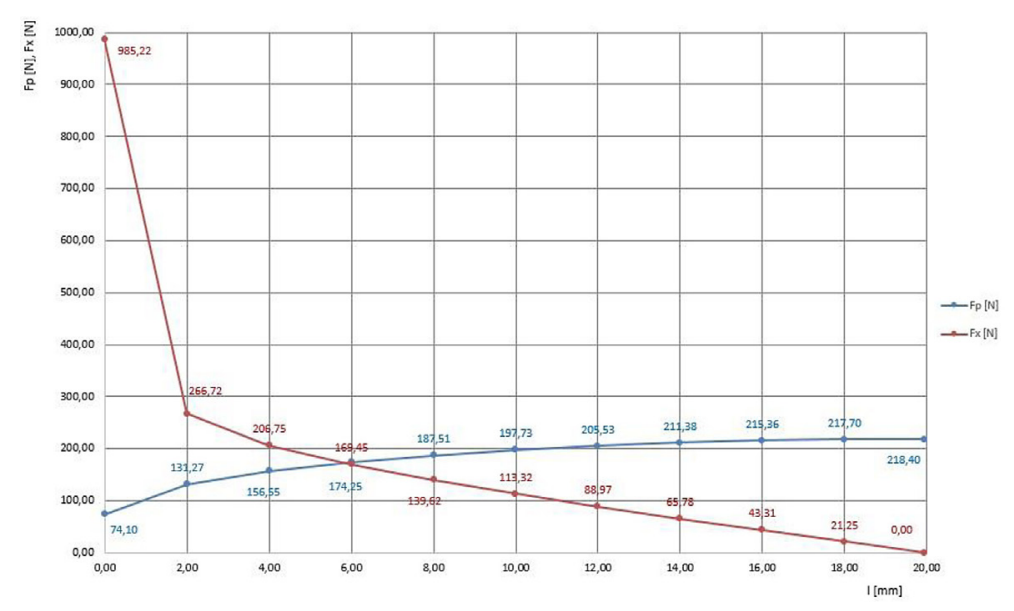

Fig. 8. Horizontal force in the axis of the pulley, vertical force exerted by the spring depending on the horizontal displacement of the pulley axis 

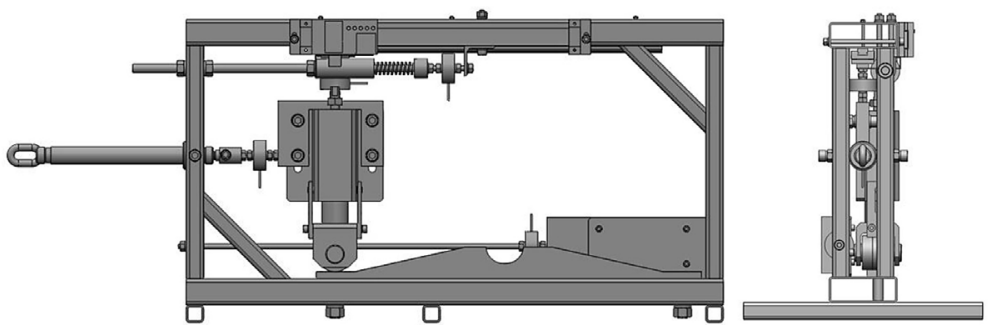

Fig. 9. Model of experimental device for verification of acting forces created in the environment

\section{CONCLUSION}

The automatic parking system, after lifting the pallet with the vehicle to the floor designated by the control system, moves the pallet using a chain conveyor to the taxiway in the parking box provided with plastic rollers. Achievement of the correct parking position is identified by sensors located on each floor. At this point, the controlled drive of the chain conveyor is switched off and the pallet should be locked by two mechanical brakes.

In many cases, when loading pallets with vehicles into parking boxes on sub-floors, pallets fail to reach or exceed the correct parking position. Failure to reach the correct parking position is due to the non-insertion of the locking brake pulley into the recess in the form of a circular cut-out of the brake track on the attached pallet. Exceeding the correct parking position is caused by the pallet being "over-pulled" during insertion, and thus the locking brake pulley being pushed out of the recess in the shape of a circular cut-out sector of the brake track on the pallet.

It is presented that the weakest link in the reliability of the automatic parking system is the pallet locking device, which is presented as a pallet brake. In terms of mechanical principle, this is not a real brake, but a locking mechanism with a spring and a rotary pulley which, in addition to locking the pallet in the parking position, is able to partially brake and stop the pallet.

The purpose of the paper was to determine the actual theoretically acting forces and kinematic ratios in play during the guiding / pushing of the locking brake pulley into/out of the recess in the form of a circular cut-out sector of the brake mounted on the pallet. These theoretical conclusions will now be verified on a model device where the actual forces applied to guide the pallet to the correct parking position will be experimentally obtained. The applied force values obtained will be used to modify the software that controls the speed of the chain conveyor drive and thus the speed of the chain movements so as to achieve, as accurately as possible, the guiding of the brake pulley into the recess in the pallet brake track and thus the exact parking position of the pallets loaded with vehicles for the automated "MULTI TOWER" parking system.

\section{Acknowledgements}

This work has been supported by The Ministry of Education, Youth and Sports of the Czech Republic from the Specific Research Project SP2019/101 and a Contract for work No. S40/19-342-01.

\section{REFERENCES}

1. KOMA, 2019, http://komaparking.cz/parkovacisystemy/

2. SpecialSprings, 2019, http://specialsprin gs.com/en

3. Hrabovský, L., Mantič, M., Voštová, V., Adhesion Coefficient on the Limit of Slippage at Star-Up of the Manual Crane Trolley. Advances in Science and Technology Research Journal, 2, May 2019, 92-99. DOI: 10.12913/22998624/106244.

4. Hrabovský, L., Apparatus Producing an Even Distribution of Strain into Carries. World Multidisciplinary Civil Engi-neering - Architecture - Urban Planning Symposium, 245, 2017, 1-6. DOI: $10.1088 / 1757-899 X / 245 / 2 / 022097$.

5. GDMUTRADE, 2018, www.qdmutrade.com/ nav/27.html

6. PARKPIU, 2019, https://www.parkpiu. com/

7. Robotic Parking Systems, 2019, https://www.roboticparking.com/roboticparking_rps_100.htm

8. Hrabovský, L., Maslarić M.: Device designed for detection and setting the required tensile force in ropes. Advances in Science and Technology Research Journal, 12(1), 2018, 200-206, DOI: $10.12913 / 22998624 / 86614$. 